\title{
Acute Supratentorial Ischemic Stroke: When Surgery Is Mandatory-A small review
}

\author{
Amit Kumar Ghosh* \\ Department of Neurosurgeon, National Neuroscience Institute, India
}

Submission: September 24, 2018; Published: October 11, 2018

*Corresponding author: Amit Kumar Ghosh, Department of Neurosurgeon, National Neuroscience Institute, India, Email: amitghosh74@yahoo.co.in

\section{Abstract}

Massive supratentorial infarct due to large vessel occlusion results death which can be prevented by early decompressive craniectomy rather than delayed. This is a short review of those clues to decide which cases will need early surgery.

Abbreviations: MCA: Middle Cerebral Artery; ICA: Internal Carotid; ICP: Intracranial Pressure

\section{Introduction}

Massive brain swelling may occur in $10 \%$ of cerebral ischemic strokes. In these patients the clinical presentation usually starts with focal signs (motor weakness, speech disturbances, and hemianopsia) and progresses with a decline of consciousness (drowsiness, stupor). Despite optimal medical management this condition may lead to death in $70-80 \%$ of cases Because of the grim prognosis, this condition has been termed "malignant" cerebral infarction. The etiology is the occlusion of a large vessel, primarily the Internal Carotid (ICA) or the Middle Cerebral Artery (MCA).

Decompressive surgery seems to be more effective if performed earlier rather than later. That is why, there is great interest in identifying clinical, laboratory, and imaging findings which is able to predict which patients are going to develop a malignant infarction.

Clues to detect ischemic patients at higher risk for a malignant supratentorial (MCA) infarction who will require surgery [1].

\section{Clinical}

Signs of raised intracranial pressure specifically progressive deterioration of consciousness. But, decrease in consciousness level may be due to shift of the ischemic tissue rather than raised Intracranial Pressure (ICP). So, clinical data must be correlated with Imaging findings.

\section{Radiological}

\section{CT scan/perfusion-CT}

a. Area compromised $>50 \%$ MCA territory

b. Perfusion drop $>66 \%$ an infarct extending also to the anterior or posterior cerebral artery territories. c. A midline shift $>10 \mathrm{~mm}$, effacement of subarachnoid spaces, and attenuation of corticomedullary differentiation are also related to higher risk of severe deterioration.

\section{MRI/DWI}

Ischemic area > $145 \mathrm{~mL}$, even at early stages. Moreover, DWI ischemic volumes larger than $210 \mathrm{~mL}$ were found related to a $100 \%$ mortality in patients without surgical treatment Laboratory data [1] (Figures 1\&2).

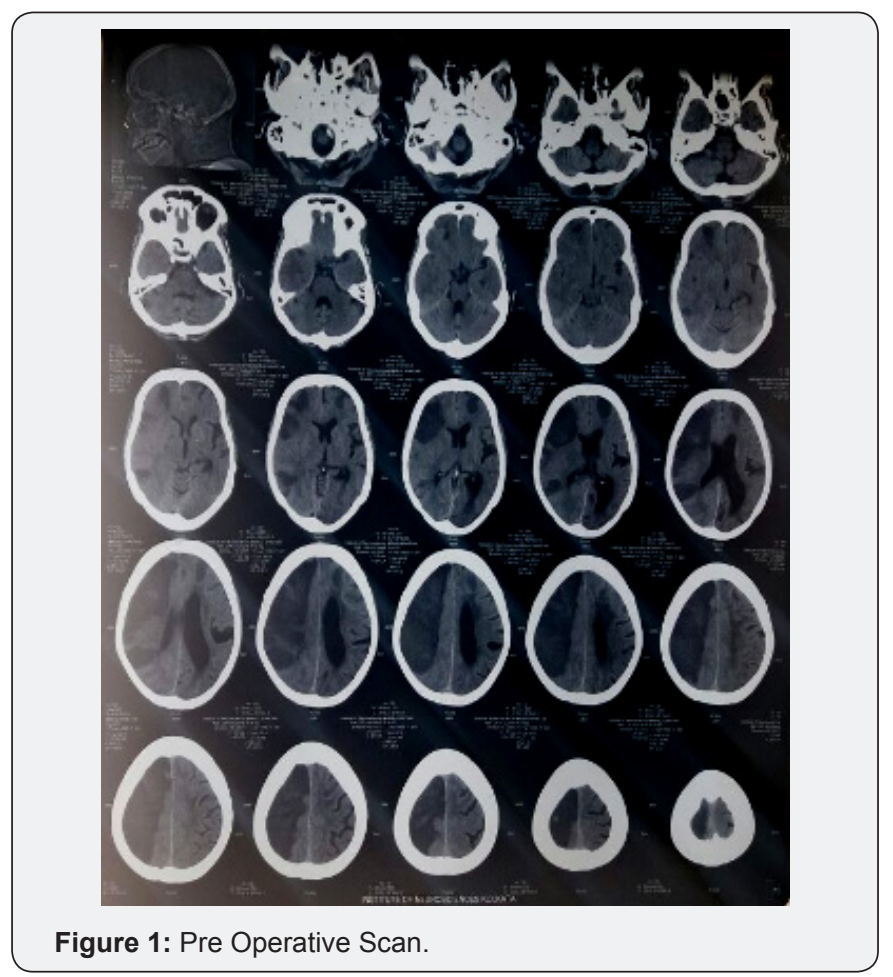




\section{Open Access Journal of Neurology \& Neurosurgery}

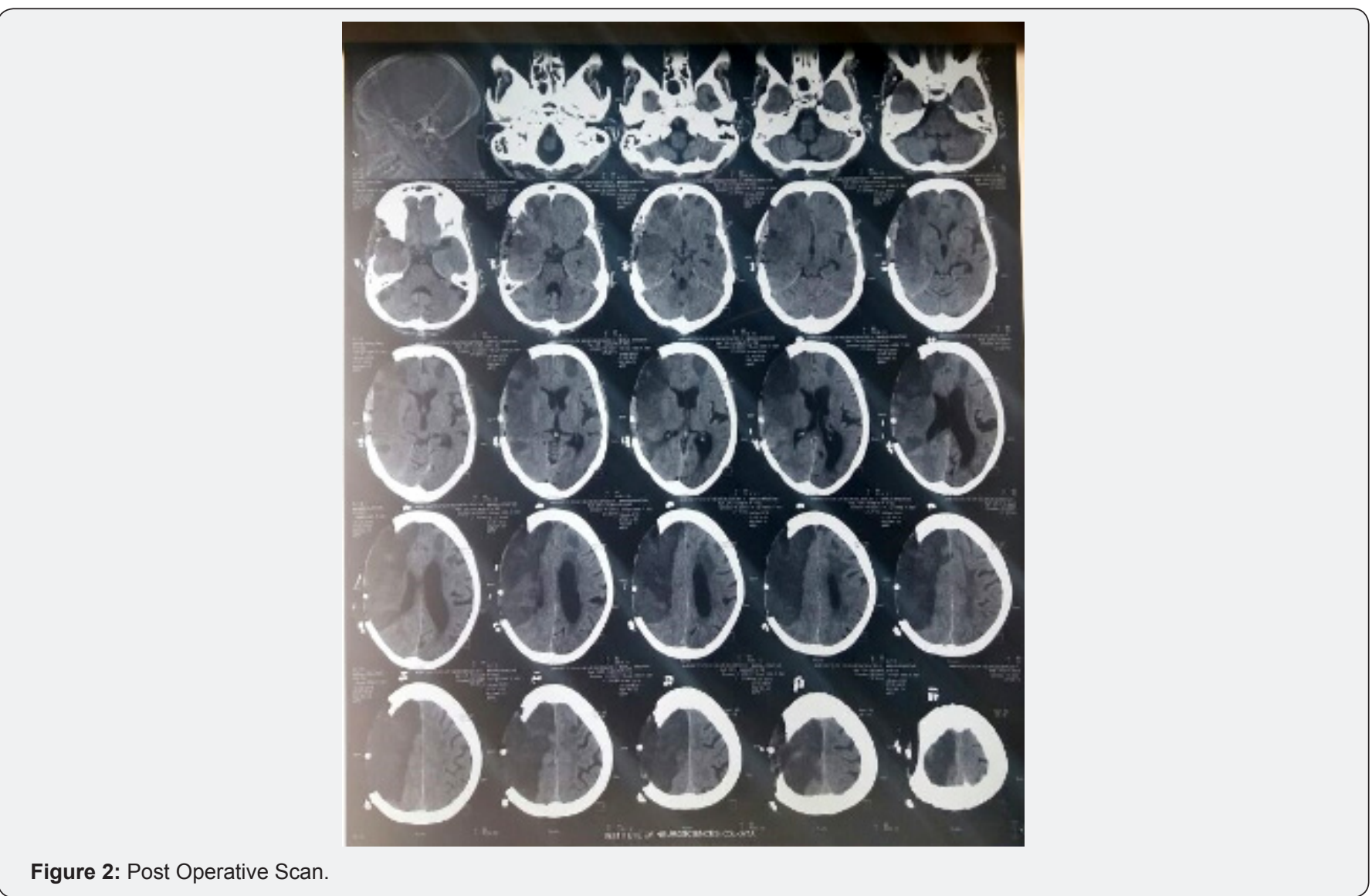

Serum astroglial protein S100B protein $>1.03 \mathrm{mcg} / \mathrm{L}$ (Has $94 \%$ sensitivity and $83 \%$ specificity to predict massive cerebral edema) Unfortunately at this stage, this tool is not available in every hospital.

\section{Intracranial pressure (ICP) monitoring}

The role of ICP monitoring in patients with large cerebral infarctions is controversial. There is no absolute recommendation for a routine use of intracranial pressure monitoring. And it is not considered a risk-free procedure. Uncal herniation and anisocoria sometimes occur without an overall increase of ICP. In patients with a malignant MCA infarction, pupillary abnormalities and severe brainstem compression may be present despite normal ICP values. Therefore, continuous ICP monitoring cannot substitute for close clinical and radiological follow-up in the management of these patients. Other facts $[2,3]$.

The side of the stroke does not seem to affect the vital status after surgical decompression, so it should not influence the choice to operate Patients older than 60 years are not ideal candidates for surgical decompression as they possess a lower neuronal plasticity and also frequently have more risk factors and comorbidities. However, older patients with a good antecedent condition hemicraniectomy seems somehow to improve the prognosis Surgery can be safely performed even after intravenous tissue plasminogen activator administration for thrombolysis.

\section{Technical}

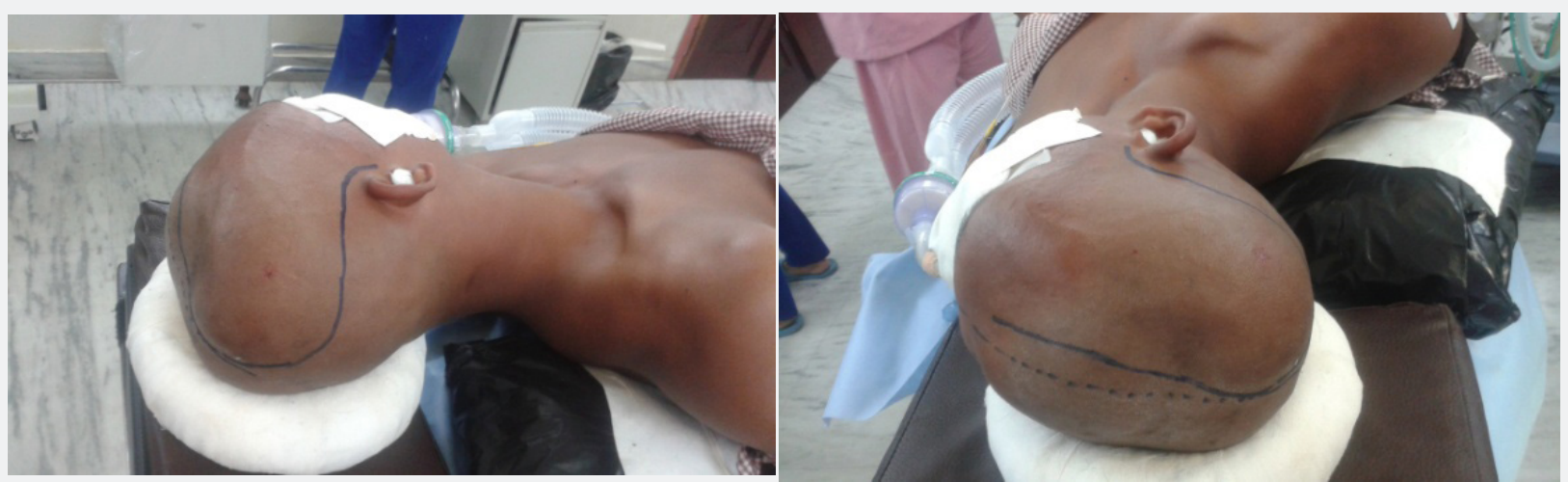

Figure 3: Incision. 


\section{Open Access Journal of Neurology \& Neurosurgery}

The craniotomy should include the frontal, parietal, and temporal bones and its antero-posterior length should not be inferior to $12 \mathrm{~cm}$ larger openings up to $14 \mathrm{~cm}$ or more are thought to allow an even better pressure relieve. Particular attention has to be paid to decompression of the basal temporal area, as it represents a critical compartment with close relationship with the brainstem. In order to gain additional room, the dura mater is commonly opened as well. It can then be enlarged with a biological or synthetic substitute or left patent, just covered by hemostatic material for a faster closure the cerebral tissue itself should be completely preserved at surgery for recovery of the not deadly damaged areas, which may be not distinguishable from the infarction itself (Figure 3).

\section{Conclusion}

No absolute criteria for selection of surgical cases in stroke. a. Clinical and radiological correlation,

b. Co-morbidities

c. Eagerness of family members to accept the disability

d. Cost factor for post-surgical rehabilitation in home.

\section{References}

1. Gabriele Ronchetti, Pier Paolo Panciani, Roberto Stefini, Giannantonio Spena, Marco Maria Fontanella (2013) Acute Supratentorial Ischemic Stroke: When Surgery Is Mandatory. BioMed Research International 2014: 6 .

2. Poca MA, Benejam B, Sahuquillo J, Riveiro M, Frascheri L, et al. (2010) Monitoring intracranial pressure in patients with malignant middle cerebral artery infarction: is it useful? J Neurosurg 112(3): 648-57.

3. Ghosh Amit Kumar (2017) Different methods and Technical considerations of Decompressive Craniectomy in the Treatment of Traumatic Brain Injury -A review. Indian J Neurosurg 6: 36-40.

This work is licensed under Creative Commons Attribution 4.0 Licens

DOI: 10.19080/OAJNN.2018.09.555760

\section{Your next submission with Juniper Publishers} will reach you the below assets

- Quality Editorial service

- Swift Peer Review

- Reprints availability

- E-prints Service

- Manuscript Podcast for convenient understanding

- Global attainment for your research

- Manuscript accessibility in different formats ( Pdf, E-pub, Full Text, Audio)

- Unceasing customer service

Track the below URL for one-step submission https://juniperpublishers.com/online-submission.php 